\title{
FLOWERING INTENSITY AND FLOWER VISITORS OF Santalum album L. AT EX-SITU CONSERVATION PLOT, WATUSIPAT, GUNUNG KIDUL, YOGYAKARTA
}

\author{
Liliana Baskorowati ${ }^{1,2}$
}

\begin{abstract}
Flowering intensity, insects visiting flowers and pollinators of $S$. album were determined in a study conducted in an ex-situ conservation plot, Watusipat, Gunung Kidul, Yogyakarta. Observations were undertaken during flowering season in 2009 and 2010, with an objective to determine the patterns of flowering and flower visiting insects of $S$. album in this population. In this study site, S. album typically flowers twice a year and reaches a peak on June and November. Flowers are visited by various insects, major in honey bees and ants. Santalum album is predominantly cross pollinated by insects however, low number of fruit set found in an open pollination. Variation of flowering intensity and the degree of self-incompatibility may influence the low number of fruit production in this species.
\end{abstract}

Keywords: Santalum album, insects, flowering intensity, pollination

\section{INTRODUCTION}

The aim of pollination management is to produce optimal quality and quantity of seed (Sedgley and Griffin, 1989). To actively manage pollination, it is necessary to understand the behavioural characteristics of major pollinators of specific species. This factor is important as other aspects of reproduction biology (Frankie and Haber, 1983).

In non-wind-pollinated species, flowers are visited by a variety of pollen vectors; however, the vector capability to remove and deposit pollen varies accordingly (Faegri and van der Pijl, 1979; Carthew, 1993). The feeding behaviour and size of insect visitors, for example, influence the effectiveness of transferring pollen to stigma (Sedgley and Griffin, 1989; House, 1997). Ineffective pollinators may reduce reproductive success, due to clogging the stigma with incompatible pollen (Waser, 1983). Primack and Silander (1975) stated that pollinator effectiveness depends on their ability to transfer pollen between stigmas, flowers and trees, and the frequency with which pollinators visit individual flowers.

\footnotetext{
${ }^{1}$ Center for Forest Biotechnology and Tree Improvement Research, Jl. PalaganTentaraPelajar Km. 15, Purwobinangun, Pakem, Sleman, Yogyakarta, Indonesia.

${ }^{2}$ E-mail: lbaskorowati@yahoo.com
} 
Pollinator foraging behavior is often closely related to the local flower density (Levin, 1978; Zimmerman, 1988). For instance, House (1997) reported that E. stellulata that total insect visitations in late peak flowering were higher than in early peak flowering. Trees that produced most flowers also attracted the largest numbers of visiting insects.

Santalum album naturally occurs, in India, Eastern Java, Timor and Sumba (Harisetijono and Suriamihardja, 1993; Doran and Turnbull, 1997). This species is one of the most valuable oil-bearing species. Therefore, an understanding of reproductive biology of this species is necessary for breeding programs. Previous studies of flowering and fruiting of $S$. album in a natural population in Java, Indonesia revealed that flowering time of its species occurs from June to October (Haryanto et al., 2005; Prasetyaningtyas, 2005). Flowering time of this species depends on the locality; for example, a population in India flowered twice throughout the year in a single population (Srimanthi, 1983). Summaries of flowering pattern of S. album presented in Table 1.

Table 1. Summaries of flowering pattern of S. album

\begin{tabular}{ll}
\hline Peak flowering of S. album & Author, Year \\
\hline $\begin{array}{l}\text { In India, flowering from July to September } \\
\text { fragmentary flowering occurs in other months of the } \\
\text { year }\end{array}$ & $\begin{array}{l}\text { Srimanthi, 1983 } \\
\text { Veerendra HCS and } \\
\text { Padmanabha HAS, 1996 }\end{array}$ \\
\hline $\begin{array}{l}\text { In China, flowering from June to August with } \\
\text { fragmentary flowering occurs in other months, } \\
\text { florescence vary between different trees }\end{array}$ & Ma et al., 2006 \\
\hline In Indonesia, flowering from June to October & $\begin{array}{l}\text { Ratnaningrum and } \\
\text { Prehaten, 2005 }\end{array}$ \\
& Prasetyaningtyas, 2005 \\
\hline
\end{tabular}

Natural pollination and fruit set in S. album are usually low with high heterozygosity, genetic variation and abnormality in succeeding generations (Bagachi and Kulkarni, 1987; Brand, 1994; Fox et al., 1995; Suma and Balasundaran, 2003). According to Bhaskar (1992) and Jyothi et al. (1991), S. album is predominantly outbreeding and self-incompatible species, although its flower structure was designed for self-pollination; suggesting that pollination system of S. album depends on the agent of pollination. This study conducted in order to understand the management of ex-situ conservation plot of $S$. album based on the information of reproductive biology. Therefore, this paper presents observations on the flowering intensity and the pollinator of $S$. album in an ex-situ conservation plot, Watusipat, Gunung Kidul, Yogyakarta. 


\section{MATERIALS AND METHODS}

\section{A. Materials}

Assessment of flowering intensity and observation of pollinator were undertaken at $S$. album ex-situ conservation plot in Yogyakarta, Indonesia (Figure 1). This plot was established in 2003 with the total of 280 trees, consisting of 14 provenances from Alor, Timor, Sumba and Java.

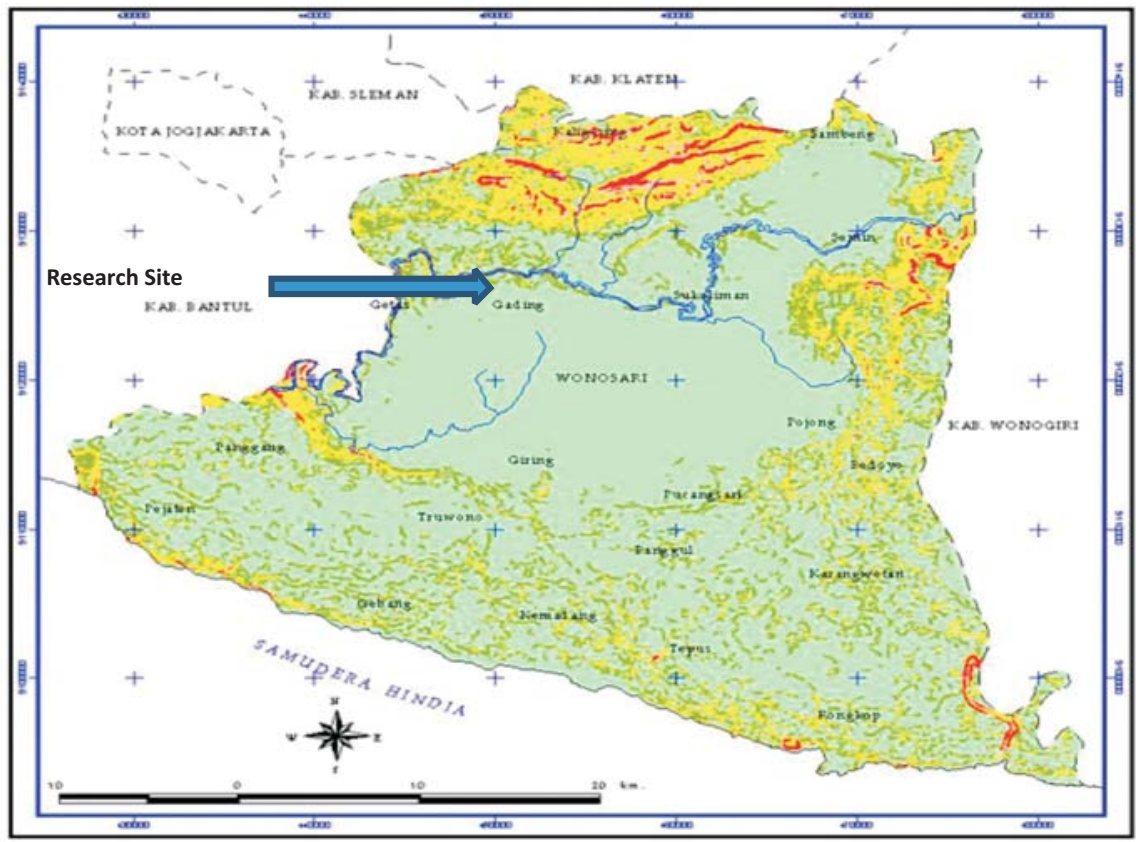

Figure 1. Study site (Ex-situ conservation plot of Santalum album at Watusipat, Gunung Kidul, Yogyakarta

\section{B. Methods}

\section{Experiment 1: Flowering time and intensity}

The study was conducted over 14 months and during this period, flowering occurred three times, which peaked in May - June 2009, December 2009 - January 2010 and May - June 2010 as described in Figure 1. Observations of flowering intensity and pollinator were undertaken during peak flowering in December 2009 - January 2010 and May - June 2010. All individual trees growing in this plot were tagged and numbered for identification purposes. The number of flowers of each individual tree 
was recorded based on the score of tree bearing flowers. Four point scales were used in this observation (Sedgley et al., 1991), 0 = no flower, 1 = light flower, 2 = medium flower, 3 = abundance flower.

\section{Experiment 2: Insects visiting flowers}

Observation of floral visitor and pollinator were observed on the 12 trees. Those trees were chosen based on the flowering abundance (scored 3 data from experiment 1). Observations were caried out twice, during 2 consecutive years. In December 2009 January 2010, each sample tree had score 3 (abundance flowers) at the time of investigation. One five-minute count of insect visitation was undertaken each morning between 07.00 and 08.00 over two consecutive days. On May - June 2010, one fiveminute count of insect visitation was also carried out during 3 time periods; i.e. at morning time between 9.00 and 10.00; at noon between 12.00 and 13.00 and at afternoon between 15.00 and 16.00 over three consecutive days. All insect visits to each spike were recorded and sampled of insect visitor were also collected at this site during these two daily periods. Insects observed on flowers were caught by a trapping net and specimen were stored individually in sterilized glass bottles and preserved in $70 \%$ ethanol solution for identification.

\section{Experiment 3: Netting observations}

In order to determine the pollinator, exclusion experiments were undertaken during December 2009 - January 2010 and May - June 2010. Small branches in close proximity were allocated randomly to the following treatments: (1) complete exclusion by non-woven polyester bags (PBS 10-1); (2) partial exclusion by fiber glass fly-screen with $2 \mathrm{~mm}$ apertures; (3) partial exclusion by steel chicken wire with $5 \mathrm{~mm}$ apertures; (4) partial exclusion by steel chicken wire with $10 \mathrm{~mm}$ apertures; and (5) no exclusion (open pollination). Approximately 100 flowers were allocated to each of the five treatments in each sample tree, depending on the numbers of flower availability. All open flowers and previous flower crops were removed from the branch. The number of buds was counted and recorded before applying the experimental treatment. All treated branches were then clearly labeled using a color tag. All bags and nets were removed from each branch after three weeks, when all stigmas had reached the post-receptivity stage. Capsule inspections and a final count were made two months later.

\section{RESULTS AND DISCUSSIONS}

\section{Experiment 1: Flowering time and intensity}

Over 14 months study, flowering of $S$. album occurred three times, which peaks in May - June 2009, December 2009 - January 2010 and May - June 2010 as described in 
Figure 2. The observations revealed that $S$. album in ex-situ conservation plot in Yogyakarta, Indonesia flowered twice a year. Fragmentary flowering may also occur in other months of the year and florescence may vary between different trees. During a year, this population commenced to flower in April which peaked in June, the second flowering comenced on November and peaked at the end of December. Flowering intensity between individual trees varied significantly. It was recorded during May 2010 that from 280 individual trees, $48 \%$ of the trees had no flowers at all, $24 \%$ had light flowering, $12.2 \%$ showed medium flowering and 13.2\% exhibited abundance flowering.

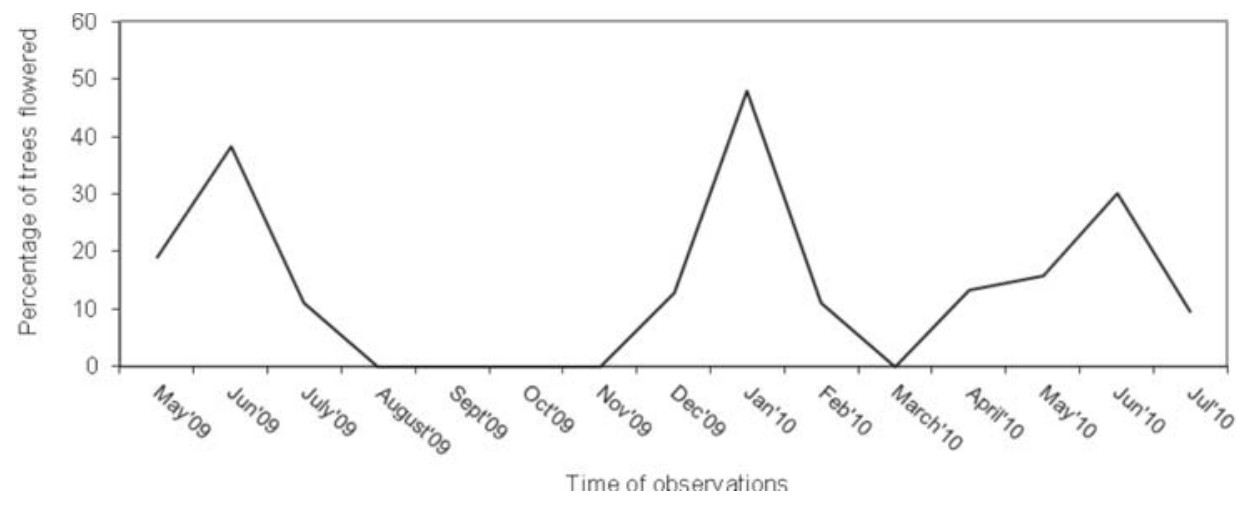

Figure 2. Flowering pattern of Santalum album in ex-situ conservation plot, Watusipat, Gunung Kidul, Yogyakarta during 2009 and 2010 flowering seasons

This finding is slightly different from the previous result by Prasetyaningtyas (2005) which observed the population of S. album in Wanagama Research Forest, Gunung Kidul, Yogyakarta. The flowering peak was in July, with only $18.15 \%$ trees bearing flowers. The variation of flowering and fruiting seasons of $S$. album vary depending on locality. In India, most trees usually flower and fruit twice a year with the first flowering begins in May - end of dry season, with fruit maturity commencing in September-end of wet season; and the second flowering commences in November with fruit maturity commencing in February (Srimanthi et al., 1995). Moreover, Srimanthi (1983) stated that flowering may appear once, twice and throughout the year in a single population. In Guangzhou, China, S. album flowers between March and May (Ma et al., 2006).

Furthermore, the time, frequency and intensity of flowering vary within a species (Smith-Ramirez and Armesto, 1994). This variation is due to genetic differences (Eldridge et al., 1993; Friedel et al., 1993) also modified by abiotic and biotic factors such as climate (photo period, temperature and precipitation), geographical influences of 
latitude, longitude and altitude, heat sum, competition for pollinators, maternal resources and seed dispersal, life form, phylogenetic constraints, and inflorescence architecture (Keatley and Hudson, 1998). To date, the variation in flowering of eucalypts has been attributed mainly to climatic and geographical influences (Ashton, 1975; Griffin, 1980; Friedel et al., 1993).

\section{Experiment 2: Insects visiting flowers}

Observation of insects visiting flowers of $S$. album in Watusipat, ex-situ conservation plot during January 2010 flowering season, showed a variety of insect visitors. In this case, insects were identified at the family level. The Residual Maximum Likelihood analysis applied to these data investigated the variation in insect visitors at the family level, with this factor as fixed effect and provenance (sample trees) as a random effect. The number of insects of different families visiting flowers varied significantly (Wald stat $=60.48$; d.f. $=12$; Chi pr $=<0.001$ ).

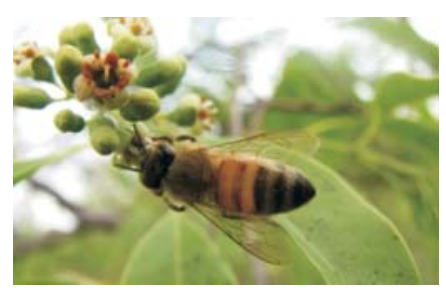

a. European honeybee

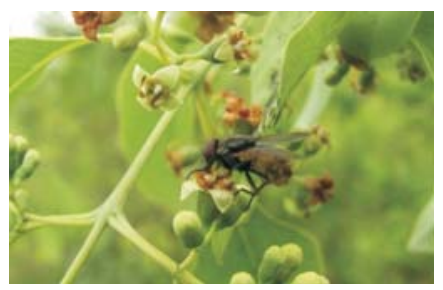

c. House fly

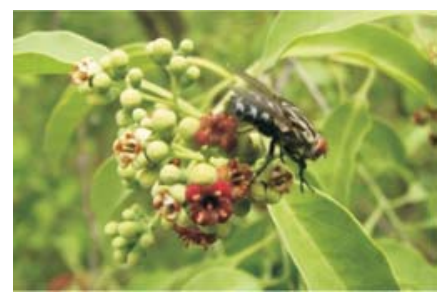

e. Green fly

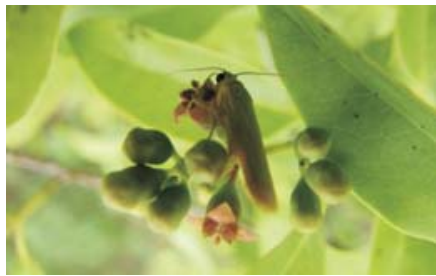

b. Small light yellow moth

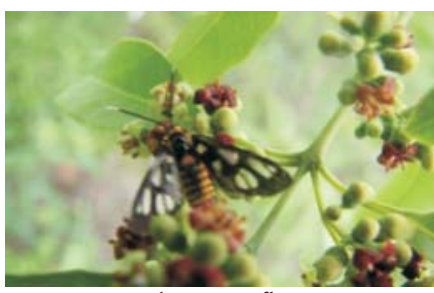

d. Butterfly

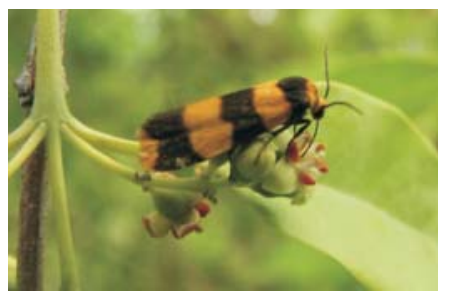

f. Orange black moth

Figure 3. Insects visiting flowers of $S$. album collected by trapping net in Watusipat, Gunung Kidul ex-situ conservation plot during January 2010 flowering season (scale $1: 1 \mathrm{~mm}$ ) 


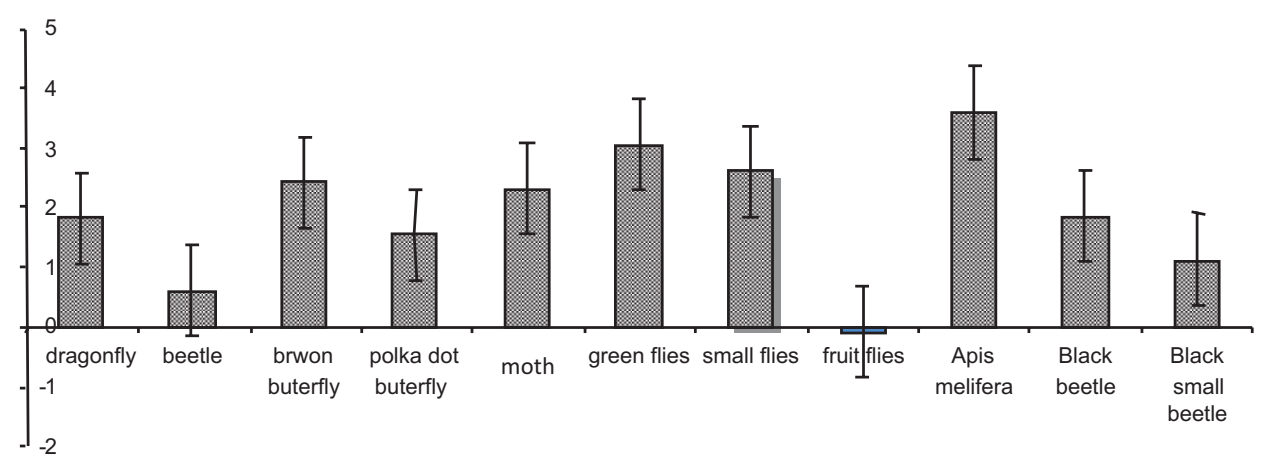

Figure 4. Mean number of insects visiting flowers of S. album during January 2010 flowering season and associated standard errors

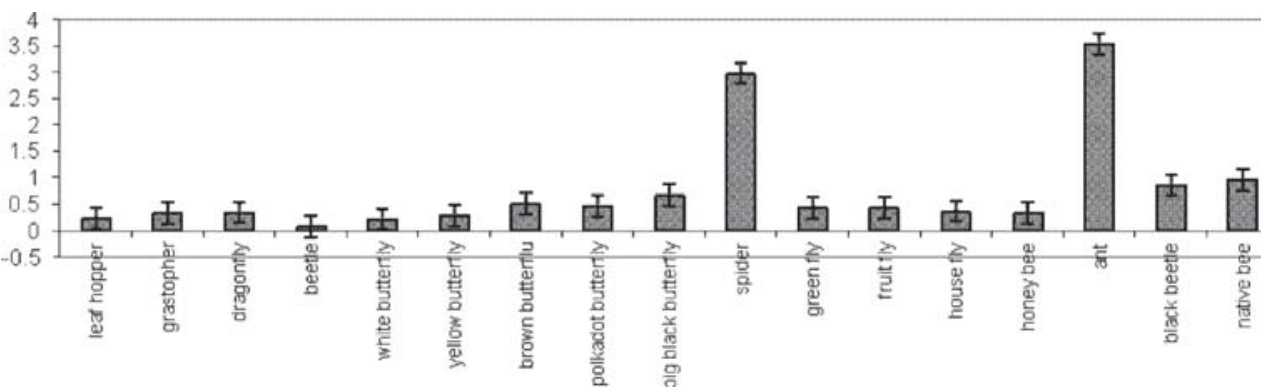

Figure 5. Mean number of insects visiting flowers of S. album during May 2010 flowering season and associated standard errors

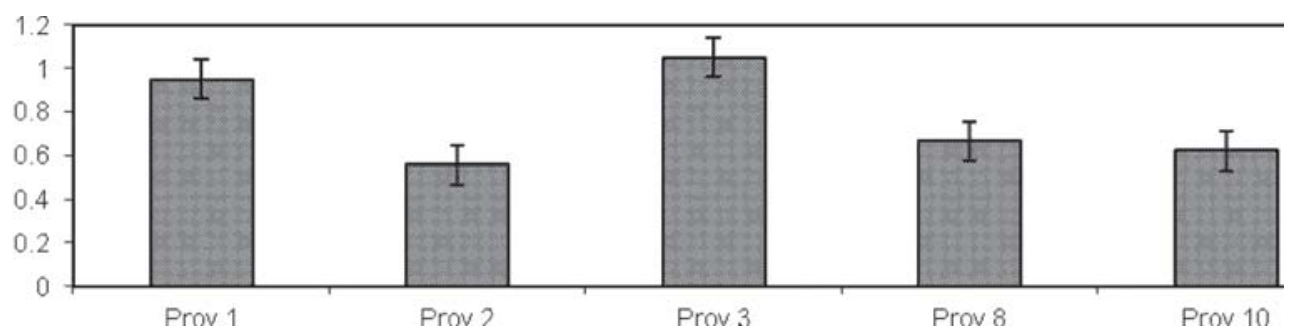

Figure 6. Mean number of insects visiting flowers of each provenances of $S$. album during May 2010 flowering season and associated standard errors

Source of provenances: P1=Omtel (Alor), P2=Aen'ut (Timor), P3=Hambala (Sumba), $\mathrm{P} 8=$ Polen $($ Timor $)$ and P10 $=$ Karangmojo (Java) 
Table 1. REML analysis of insect visitors during June 2010 flowering season

\begin{tabular}{lccc}
\hline Source of variance & $\mathrm{df}$ & Wald stat & Chi pr \\
\hline Type of insects & 16 & 117.8 & $<0.001$ \\
Provenances & 4 & 39 & $<0.001$ \\
Time of observations & 4.2 & 2 & $=0.12$ \\
\hline
\end{tabular}

Figure 4 illustrates the variety of insects visiting flowers of S. album, it shows that Apismelifera (European honey bee) comprised the majority of insects recorded visit the flowers following by green flies, small flies and brown butterfly. Whereas, no significant difference was found in the mean number of small insects between provenances (Wald stat $=17,36$; d.f. $=7$; Chi pr $=0.015$ ).

Second observation of insect visitors during June 2010 revealed similar results as January 2010. As shown in Table 1, the mean number of insects visiting flowers varied significantly in term of type of insects and the provenances as sample trees. However, mean number of insects visiting flowers did not vary. This result suggested that the time of day, and associated temperature differences did not influence the number of insect visitation to flowers (Baskorowati et al., 2010).

The variety and number of insect visiting flowers in the population of $S$. album suggested that there are no barriers to pollen transfer between trees, that rates of crosspollination in this population should be high. As mentioned above that in the first observation, Apismellifera (honey bee) was the dominant visitors of S. album; however, in the second observation flowers are predominantly visited by ants. These findings are consistent with the previous study in the pollination system of S. album in India, which revealed that 15 of different species of insects visit flowers, with ants and bees were the regular visitors (Veerendra and Padmanabha, 1996). Other studies also showed that the pollinating agents of $S$. album are ants, bees, butterflies and beetles (Sindhuveerendra and Sujatha, 1989), whereas Bhaskar (1992) stated that the commonest pollinator of this species included flies and bees, which visit the flowers for the nectar.

In this study site, two external factors influence the variation of insects visiting flowers in this population. First, during the first observation we found the hives placed in the area adjacent to this study site; and it did not present during second observation, which probably strongly influenced the number of honey bee. Second, the low flowering intensity in June 2010 compared January 2010 may result the low number of insects visiting flowers.

\section{Experiment 3: Netting observations}

Netting experiment was conducted in order to investigate what kind of insects actually act as pollinators. Five different treatments were applied in the twelve sample 
trees consists of 4 provenances and local trees. The two-way analysis of variance showed that the percentage of fruit set at 2 months after bagging varied significantly between treatments(m.s. $=8.243$, d.f. $=4$, Fpr. $=<0.001)$. While, the sample trees between the provenances were insignificantly different in term of the percentage of fruit set at 2 months after bagging (m.s. $=0.425$, d.f. $=4, \mathrm{Fpr} .=0.656$ ).

Figure 7 illustrates the percentage of fruit set for each treatment (i.e. percentage of fruit/initial number of buds). It showed that branches without any exclusion treatment had the highest percentage of fruit set; on the other hand, branches with fully closed treatment had no fruit set. Significance different between treatments using net size $(1 \mathrm{x} 1$ $\mathrm{cm}) ;(0.5 \times 0.5 \mathrm{~cm})$; and $(0.2 \times 0.2 \mathrm{~cm})$ were also revealed in this experiment; with the treatment using net $(1 \times 1 \mathrm{~cm})$ had the highest percentage compared to other net sizes.

The highest rate of capsule development occurred for the no-exclusion treatment, i.e. when all insects had open access to flowers and no capsule development revealed for the fully closed treatment. This result demonstrates that pollination leading to fruit set of $S$. album depends almost completely on insects or other animal for pollination.

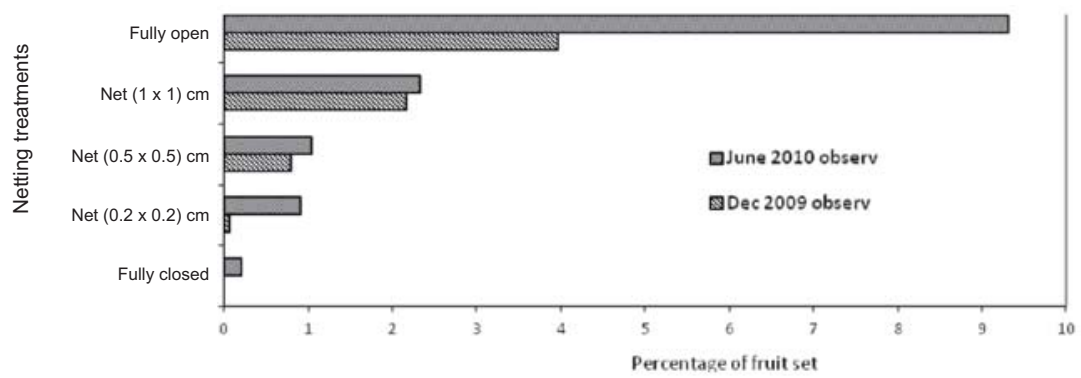

Figure 7. Proportion of $S$. album flowers that developed into fruit, under four exclusion treatments and one fully open control (Jan 2010 and Dec 2009 observations)

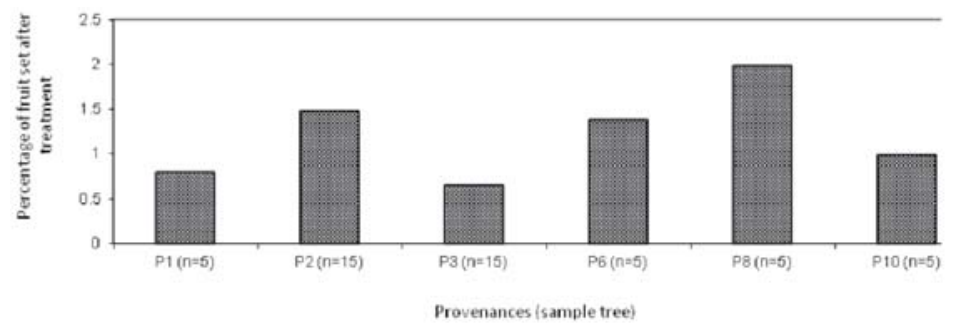

Figure 8. Mean number of proportion of S. album flowers that developed into fruit, under four exclusion treatments and one fully open of each provenance (June 2010 observation)

Source of provenances: P1 $=$ Omtel (Alor), P2 $=$ Aen'ut (Timor), P3=Hambala (Sumba), P6 $=$ Pailelang (Alor), P8 = Polen (Timor) and P10 = Karangmojo (Java) 
To further investigate on this issue, a second exclusion experiment was carried out during June 2010 comparing five treatments as previous experiment (see Figure 7). The two-way analysis of variance showed that the percentage of fruit development at 2 months after bagging varied significantly between treatments (m.s. $=11.187$, d.f. $=4$, Fpr. $=<0.001$ ) and between provenance as sample trees (m.s. $=1.969$, d.f. $=5$, Fpr. $=$ $<0.001$; see Figure 8).

In this case, the abundance of flowers of individual tree influenced the percentage of fruit set. Observation record shows that provenance 8 and 2 exhibited abundance flowers (with score 3) compared to other provenances. The abundance of flowers providing more pollens and nectar sources which attracting insects to visit flowers. As insect visits to flowers are due to the flower producing a primary attractant, such as pollen, nectar, oil and secondary attractant, such as scent and visual cues (Sedgley and Griffin, 1989).

Results on second experiment demonstrated similar result as the first experiment, in the various sizes of net and fully open treatments. However, in this experiment branches with complete exclusion treatment (fully closed) demonstrated the ability for producing fruit in the lowest percentage compared to other treatments. About $0.2 \%$ of fruit were set under the fully-bagged treatment, demonstrating that the rate of automatic self-pollination (i.e. autogamy) is very low.

The observation shows that this species is preferentially out crossing; however, the percentage of fruit set under open pollination is very low with only 4 to $10 \%$ of flowers become fruits. Previous study in S. spicatum revealed the outcrossing rate was $95.2 \%$ (Muir et al., 2007). Another study in S. album and S. spicatum showed that only $030 \%$ of flowers capable to be fruits; due to the lack of fertilization, lack of embryo sacs and failure to endosperms development (Rugkhla et al., 1997). Ma et al. (2006) in the study of S. album in China revealed that fruit set from open pollination was less than $2 \%$; however, artificial pollination could improve fruit set.

The low fruit production in this study may indicate some degree of selfincompatibility in the population. Considering that in this population no more than $50 \%$ of trees produced flowers during the flowering seasons and non-synchronicity occurred in this study site during the observations minimize the ability of flowers to attract pollinator which limit the pollen transfer between trees. Moreover, the flower structure of $S$. album was designated for self-pollination, since the time of anthesis on individual flowers within a spike is un-synchronous which may lead the differences of male and female maturation within a spike.

\section{CONCLUSION}

Santalum album in Watusipat, ex-situ conservation plot commenced to flower on April which reached the peak on June, the second flowering commenced on November and reached the peak on the end of December. In this population, flowers were visited 
by several of insects with honey bee and ants exhibited as the major flower visitors. Exclusion experiments showed that pollination leading to fruit set of S. album depends almost completely on insects or other animal for pollination, since pollination within a $1 \mathrm{x} 1 \mathrm{~cm}$ net and fully open treatments produced more fruit set compared to smaller net treatments. Very low capsule set achieved in the fully bagged treatment, which shows a degree of self-incompatibility in the population.

\section{ACKNOWLEDGEMENT}

This research was funded by Australian Center for International Agricultural Research, Canberra, Australia through John All Wright Returnee Award Program 2009 awarded to the author. Technical support was provided by Forest Biotechnology and Tree Improvement Research Institute, Yogyakarta, Indonesia. Thanks go to Mrs. Alin Maryanti, Mr. Sukidjan and Mr. Benedictus Subagyo for the field assistance.

\section{REFFERENCES}

Ashton, D.H. 1975. Studies of flowering behaviour in Eucalyptus' regnans F. Muell. Australian Journal of Botany 23: 399-411.

Bagachi, S.K. and H.D. Kulkarni, 1987. A note on seedling abnormality frequency in the half-sib progenies of Santalum album. IndianForest 113:650-651.

Baskorowati, L., M.W. Moncur, S.A. Cunningham, J.C. Doran and P.J. Kanowski, 2010. Reproductive biology of Melaleuca alternifolia (Myrtaceae) 2. Incompatibility and pollen transfer in relation to the breeding system. Australian Journal of Botany 58: 384-391.

Bhaskar, V. 1992. Pollination biology and fertilization in Santalum album L (Santalaceaea). Flora 187: 73-74.

Brand, J.E. 1994. Genotypic variation in Santalum album L. Sandalwood Research Newsletter 2: 2-4.

Carthew, S.M. 1993. An assessment of pollinator visitation to Banksia spinulosa. Australian Journal of Ecology 18: 257-268.

Doran, C.J. and J.W. Turnbull (eds.). 1997. Australian trees and shrubs: species for land rehabilitation and farm planting in the tropics. ACIAR monograph No. 24.384 p.

Eldridge, K., J. Davidson, C. Harwood and G. van Wyk. 1993. Eucalypt Domestication and Breeding. Oxford University Press, Oxford. $322 \mathrm{p}$. 
Faegri, K. and L. van der Pijl. 1979. The Principles of Pollination Ecology. Third edition, Pergamon Press, Oxford. 244 p.

Fox, J.E.D., J.E. Brand, D.R. Barret and E. Markhum. 1995. Genetic variation in Santalum album in Timor. In: Gjerum L., J.E.D. Fox and L. Erhart (Eds.) Sandalwood seed nursery and plantation technology. Food and Agriculture Organization (FAO), Suva. Pp. 93 - 110.

Frankie, G.W. and W.A. Haber. 1983. Why bees move among mass-flowering neotropical trees. In: C.E. Jones and R.J. Little (Eds.). Handbook of Experimental Pollination Biology.. Scientific and Academic Editions, New York. Pp 360-372.

Friedel, M.H., D.J. Nelson, A.D. Sparrow, J.E. Kinloch and J.R. Maconochie. 1993. What induces central Australian arid zone trees and shrubs to flower and fruit? Australian Journal of Botany 41: 307319.

Griffin, A.R. 1980. Floral phenology of a stand of mountain ash (Eucalyptus regnans F. Muell) in Gippsland, Victoria. Australian Journal of Botany 28: 393404.

Harisetijono and Suriamihardja, 1993. Sandalwood in Nusa Tenggara Timur. In: McKinnell, F.H. (Ed.) Sandalwood in the Pacific Region. Proceedings of a symposium held on 2 June 1991 at the XVII Pacific Science Congress, Honolulu, Hawaii. Canberra ACIAR Proceedings No.49. Pp 39-43.

Haryanto, Y., M. Na'iem, Y.W.N. Ratnaningrum and D. Prehaten. 2005. Enhancing pollination effectiveness and crossing rate on the low seed set and mixed mating systems endangered species (Santalum album Linn., Santalaceae): Effect of pollen quantity and pollen sources on seed production. In: Mason, E., A. Rimbawanto, K.L. Ginoga, Hendromono and T.E. Komar (Eds.). Proceeding of the International Seminar on Plantation Forest Research and Development. Center of Forest Biotechnology and Tree Improvement, Yogyakarta. Pp. 141149.

House, S.M. 1997. Reproductive biology of eucalypts. In: Williams J.E. and J. C. Z. Woinarski (Eds.). Eucalypt ecology. Cambridge University Press, Cambridge. Pp. 30-50.

Jyothi, P.V., J.B.Alturi and R.C. Subba, 1991. Polination ecology of Santalum album (Santalaceae). Tropical Ecology 32: 92104.

Keatley, M.R. and L. Hudson, 1998. The influence of fruit and bud volumes on eucalypt flowering an explanatory analysis. Australian Journal of Botany 46: 281304.

Levin, D.A. 1978. Pollinator behaviour and the breeding structure of plant populations. In: A.J. Richard. The Pollination of Flowers by Insects.Academic Press, London. Pp. 133 - 150. 
Ma, G., E. Bunn, J. Zhang and G. Wu. 2006. Evidence of dichogamy in Santalum album L. Journal of Integrative Plant Biology 48(3): 300-306.

Muir, K., M. Byrne, E. Barbour, M.C. Cox and J.E.D. Fox. 2007. High levels of outcrossing in a family trial of Western Australian Sandalwood (Santalum spicatum). Silvae Genetica 56(5): 222-230.

Prasetyaningtyas, M. 2005. Studi fenologi pembungaan dan penyerbukan Santalum album Linn. Master Thesis Program Pasca Sarjana Universitas Gadjah Mada, Yogyakarta. Unpublished.

Primack, R.B. and J.A. Silander. 1975. Measuring the relative importance of different pollinators to plants. Nature 255: 143-144.

Ratnaningrum, Y.W.N. and D. Prehaten. 2005. Pollination mechanism and breeding system of Santalum album (Santalaceae), the endemic species of Eastern Parts of Indonesia that became landcare of GunungKidul, Central Java. In: Proceeding Forestry International Seminar. Universitas Putra Malaysia. Bintulu. Malaysia.

Rugkhla, A., J.A. McComb and M.G.K. Jones. 1997. Intra- and inter-specific pollination of Santalum spicatum and S. album. Australian Journal of Botany 45: 1083-1095.

Sedgley, M. and A.R. Griffin. 1989. Sexual Reproduction of Tree Crops. Academic Press, London.

Sedgley, M., W.C. Yong, V. Newman, J. Harbard, R.M. Smith, K.K. Gan and A. Tadjudin. 1991. Phenology of Acacia mangium and Acacia auriculiformis in Australia and Malaysia, ACIAR Workshop on Hybridization and Vegetative Propagation of Tropical Acacias, $14^{\text {th }}$ July Canberra.

Smith-Ramirez, C. and J.J. Armesto. 1994. Flowering and fruiting in the temperate rain forest of Chiloé, Chile-ecologies and climaticconstraints. Journal of Ecology 82: 353-365.

Srimanthi, R.A. 1983. Breeding of sandal. A tropical hardwood tree. Current status and future prospects. ISTS Symposium on Advance in tree species. Forest Research Institute, Dehra Dun, India.

Srimanthi, R.A., H.D. Kulkarni and K.R.Venkatesan. 1995. Recent Advances Research and Management of Sandal (Santalum album L.) in India. The Associated Publishing Company, New Delhi. Pp 416.

Suma, T.B. and M. Balasundaran. 2003. Isozyme variation in five provenances of Santalum album in India. Australian Journal of Botany 51:243-249. 
Veerendra, H.C.S. and H.S.A. Padmanabha. 1996. The breeding system in Sandal (Santalum album L). Silvae Genetica 45(4): 188-190.

Waser, N.M. 1983. The adaptive nature of floral traits: ideas and evidence. In: L. Real (Ed.). Pollination BiologyAcademic Press, Florida. Pp. 242-277.

Zimmerman, M. 1988. Nectar production, flowering phenology and strategies for pollination. In: J. Lovett Doust and L. Lovett Doust (Eds.). Plant Reproductive EcologyOxford University Press, Oxford. Pp. 157-178. 